\title{
She knew all about hard times. Memories of Lil Tate, Auckland social Worker, 1935-1962
}

\author{
Margaret Tate
}

The author lived in Ponsonby throughout the 1940s and attended Richmond Road School, Auckland Girls' Grammar School and Auckland University where she graduated with an MA in English. While a student she worked part-time at the Auckland (Anglican) City Mission and gained insight into the life of the inner city. She married Lil Tate's son Graham who became Professor of Computer Science at Massey University and after some years of family life she became a Senior Lecturer at the Palmerston North College of Education.

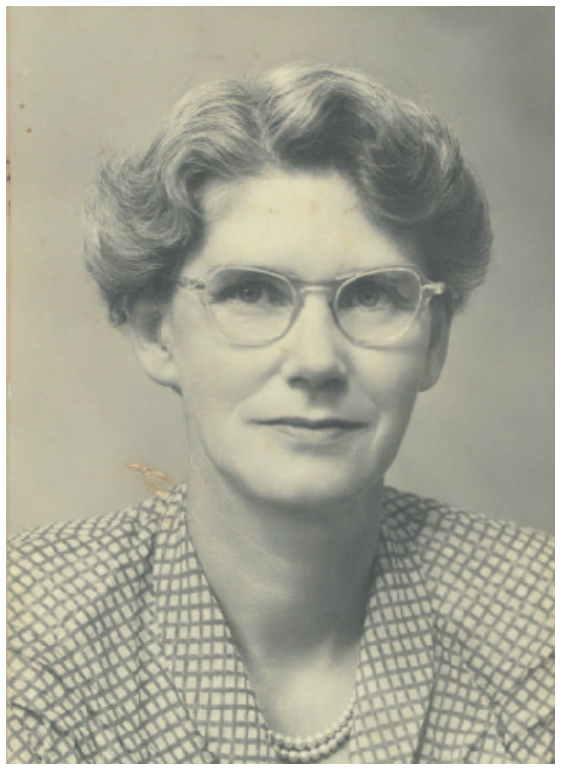

This is a personal memoir of a family member I greatly respected. It is a picture of social conditions in the inner cities in the mid-twentieth century, usually thought of as a time of general social security. It was also a time of change for the social work profession.

A few years ago I took my daughter to look at her grandmother's old home in Picton Street, Ponsonby. The plane trees in full leaf were making a green arch over the quiet street. The old villa, No.11, was freshly painted, the outside washhouse transformed and the cracked concrete in the back yard bricked over. Gentrified - as they say. We had been wandering along Ponsonby Road, now trendy with its single label dress boutiques, its retro second-hand shops and its lively baristas. It's a fun place now - but this was not the city I remember from my youth and certainly not the city where Lil Tate lived and worked.

When she came here in the 1930s, the Church of the Epiphany with its crusading City Missioner, Jasper Calder, marked one end of Ponsonby Road. At the tram terminus at the other end - The Three Lamps - was the Ponsonby Club, the old pub always known as 'The Gluepot', exuding its smell of roll-your-own cigarettes and stale beer. The shop fronts had been the same for 50 years; chemists with their huge coloured bottles in the window, butchers with sides of beef and mutton on hooks, newsagents with yellow cellophane to keep the sun off the magazines. An ordinary working class neighbourhood. But down in Freeman's Bay the crowded cottages built in the earliest years of the colony had become slums. The Depression had finished them off. Tenants could not pay the rent and the owners had no money for repairs. Some places were divided into warrens with people living on verandas, sharing a bathroom and a makeshift kitchen in the hall. Old men lived in sheds in the backyards. Children shared beds - and their infections - and parents took them to the Tepid Baths down by the wharves for a weekly bath. Industry had infiltrated these streets 
and at the bottom, the Destructor poured out the smoke from the burning waste of the city. Members of Parliament turned up occasionally and recommended houses to be condemned. Eventually in the late fifties, just before Lil Tate left, the process of urban renewal began

When the Labour Party was elected in 1935, their dream was to provide social security 'from the cradle to the grave'. The cheerful families so often photographed in their bright state house kitchens were undoubtedly better off, but poverty did not disappear overnight. Old people, wholly dependent on the pension could barely make ends meet and the wives of alcoholics and other 'no hopers' were even worse off. They were commonly refused the charitable aid dispensed from the Auckland Hospital lest it encourage their husbands to avoid their responsibilities. They were actually better off if the man disappeared completely and they could claim support as a deserted wife - provided they could prove they were of 'good character'. Even so, charitable aid kept them in poverty when even a radio was termed a luxury and a sign of extravagance. Initially there was no sickness or invalid's benefit. Many workingmen after a lifetime of heavy outdoor work suffered from a 'crook back', hernia or chronic bronchitis and had to give up regular work. People could not pay their frequent doctor's bills and dosed themselves from patent medicines from the chemists. In the 1940s and 50s in the heyday of the Welfare State, when state houses were spreading over the outer suburbs, the inner city housed those who had slipped through the net of social security. These were the people who came to see Mrs Tate and her helpers at 11 Picton Street.

Why Lil Tate brought her family to live at Picton Street, a centre for Presbyterian social work is a long story. She was born in 1906 when her parents, Agnes and Bill Woof, were breaking in a farm in the steep, heavily bushed hills at Waitewhenua, a remote spot in the King Country west of Taumarunui. They lived at first in a ponga whare with a dirt floor. An only child, Lil papered the bare walls of her bedroom with pictures of horses cut from the racing pages of a newspaper. "My horse," she often said, "was my best friend." The Main Trunk railway was still being built and supplies came by bullock wagons or teams of packhorses along roads that were quagmires during the winter months. There was no school. At 10, she was sent to board with friends so that she could start school, but she was already tall and strongly resented being put in a primer class.

Soon after this, in 1918, Bill and Agnes, like so many early King Country farmers, walked off the land in despair and managed a boarding house in Ohura for about 10 years. Lil was needed to help in the kitchen and her short school life was over. After a few years she became desperate to get away. She met George Tate, the Irish cook at the public works camp and in 1928 married him without much ceremony at the Ohura Registry Office. She had not made a good choice.

They ran a fruit and vegetable shop first at Putaruru and then at Victoria Valley in Northland and Lil learned to drive the delivery truck on the winding gravel roads. They had two boys, Graham born in 1929 and Ormond in 1931. However George, she told us, returned to his wandering ways. Despairing of making a go of a country store in the middle of the Depression with two young children and an absent husband, Lil packed up and in 1935 went to Auckland to stay with her mother, now a widow. They rented a small house in Wood Street not far from The Three Lamps. George did turn up again, but until he left home for good in the 1950s he never held down a job. Their only income was his tiny World War I British army pension and Agnes' widow's benefit. Lil recalls having to wash the boys' 
only decent set of school clothes in the evening, dry them by the fire and sit up till they were ready to be ironed ready for the morning. She made their trousers out of old suits cut down. She would have taken any work, but even cleaning jobs were scarce when so many unemployed single women were job-hunting too.

She heard of the Sister Esther Benevolent Work and made the difficult decision to ask for help with food and clothing. This was a turning point in her life. She was given immediate help, but more important she was offered work. She began doing housework at Picton Street and some food bank deliveries. She delivered food parcels to the elderly people living on their own who had become dependent on Sister Esther. Sometimes she also had to clean up the house and persuade them to have a bath, but she seemed to enjoy visiting them and jollying them along. Knowing that she might be the only visitor they saw all week she always had time for a chat and a 'cuppa'.

They also helped the 'down and outs' and for this work Lil could draw on her own experience. She knew the ways of alcoholics at first hand. She knew better than to give them money or it would all be spent in a Hobson Street pub in five minutes. One had told her with a wink, 'A drop of whisky won't kill me. I've drunk everything from Brasso to boot polish.' But they readily offered the old rogues meal tickets for the little eating-houses where they could sit in the warm and get a plate of Irish stew and a cup of tea.

Lil learned a lot from Sister Esther - an independent and capable woman who had carried out social work from 11 Picton Street for 30 years. She was awarded an MBE in 1919 for her work with patriotic welfare groups during the War and she was one of the first women JPs in New Zealand in the late 1920s. She acted as a parole officer for girls discharged from borstal. At the onset of the Depression, when the demand became too great for an independent organisation, her work became incorporated with the Auckland Presbyterian Social Service Organisation. When she retired in 1941 because of ill health, Lil Tate was the ideal person to carry on her work.

In 1948, Lil was invited to move with her family to 11 Picton Street and this became her home for the next 12 years. She was offered free accommodation, power and groceries to help provide both for the family and for her social work. This is how family and friends remember her life there. The house was a villa built on a high basement. This basement and some of the other rooms were filled with donated clothing, bedding and furniture, which were sorted by Lil and the helpers who came from various Presbyterian women's groups. It was then shelved behind the long counter in the large front room along with the stacks of donated food. Here at Picton Street, people humiliated by the agents of official charitable aid, found friends who knew their situation personally. Hand knits for a new baby, a warm winter coat for an old lady, a good shirt and tie for an unemployed man trying to keep up appearances - all these were often specially put aside. Food parcels were wrapped neatly in brown paper and no one could tell that they were not from an ordinary grocer.

At the back of the house was a little living room that doubled as Lil's office as she gradually took on more responsibility. On pension day there were sometimes 20 or 30 people queued up along the door near the office. Lil had become the agent for their pensions and she recorded the money in little notebooks. The cash was then divided up for 
them - 2/ - for rent, 1/ - for gas and so on. The pension gave them just enough to live on and they had to get the sums right. In the days of penny-in-the-slot gas meters, if you hadn't got a penny, your gas went off and you couldn't even make a cup of tea. Lil, with her short three years at primary school, was anxious about all this arithmetic. Her student sons, both good with figures, quite enjoyed it and preparing for pension day became a family affair. Pension day was also a social occasion for the old people, who were offered a cup of tea and biscuits and often some brought a little something with them in exchange. Across the passage from the office was the kitchen and dining room, always remembered as a centre of hospitality

Soon, St James Presbyterian Church became another focus of her work. St James was a large church in Hobson St, built in 1857 but now a century later stranded with declining membership in an industrial area full of seedy shops and rundown apartments. The St James Guild of Service, led by the Minister, George Jeffreys, organised social work in the inner city supported by volunteers, mainly women, from other churches. Four photographs in a church publication show Lil's widening role. She is shown at the counter of the Picton Street clothing depot, but also at an office desk dressed in a neat dark suit interviewing a client. A photograph of the St. James Church Hall shows a large group of old ladies seated in the long pews in their best coats and hats listening to Lil, who is speaking from the stage. Some sort of official photograph shows her well dressed and smiling with other social workers and one of the St James Trustees. The 1959 Annual Report of the Presbyterian Social Services Association describes their work. Mrs Tate and Mr Jeffreys write:

We are grateful to those individuals and churches who make our work easier by providing us with clothing and other goods for distribution to people in need. We are most grateful too, for the assistance of those who have contributed financially to this work. The areas within which we have worked include the oversight of Age Beneficiaries, women in rooms, probationers, discharged prisoners, families in difficulties, unmarried mothers, adolescents, unemployed and alcoholics: these have called for the supervision of the finances of 102 people, and arrangements for accommodation on nearly 1,500 occasions, while home visits tallied more than 600 and total expenditure amounted to 4,596 pounds (p. 4).

On Sunday evening, more than 100 men gathered at the church hall for supper. Lil organised regular afternoon teas for 300 women, most of whom were living in single rooms. They had lonely lives and many gathered hours before the meeting began for the warmth and company. Once a month there would be a big jumble sale of clothing at St James and a good overcoat might sell for 1/-. Lil and her helpers kept a sharp eye on secondhand dealers and stopped them pushing in first to get a bargain.

In the fifties, the Presbyterian Church began to develop hostels and residential homes for the elderly as a new direction in social work. In the city there was a hostel for men who had been in prison, mental hospital or in treatment for alcoholism and who needed a halfway house. Lil now made arrangements for her old people to move into residential homes when they could no longer manage alone. She dropped in to see them settled and patiently listened to their complaints. 'One old biddy,' she said, 'was certain that the matron was always trying to pinch her best hat!' Eventually Lil's responsibilities included supervising the management of three of these homes. There were still sad occasions when an old person would be found dead in their house and she would be called on to sort things out. People knew she would not refuse such jobs either. 
More work was now being referred to her from Government agencies. In an article in the Waikato Times written when she was leaving Auckland, Lil described her work:

The majority of my work in Auckland was with families but there was also much to do for the unmarried mothers and children in need of foster homes ... Much of my work in Auckland were referred to me by the Child Welfare Department, church ministers and the Courts.

Twenty years before the introduction of the Domestic Purposes Benefit, the general view was that single mothers were to blame for their misfortunes. They were able to receive an emergency sickness benefit only for the period of their confinement. They were pressured into having their babies adopted and keeping the whole business a secret. Those who kept their babies often ended up being paid a pittance for the ambiguous duties of housekeeper to a widower or single man. One single mother, who became like a daughter to Lil, recalled in a private letter to the author her unusual sensitivity and understanding:

My reason for getting in touch with Lil was that as an unmarried expectant mother from Sydney I had come to New Zealand - as the trend at the time was to be sent away out of sight of prying eyes of family and friends. Lil showed understanding and care, treating me as a worthy person and helping me in so many small ways as well as emotional times. Lil arranged for expectant mothers to live in private homes and it was wonderful to be accepted as an extra member of the family. Adoptions were also arranged by Lil and then approved by Social Welfare. She was brilliant matching the adoptive parents with the background of the child. She visited the 'to be' parents in their homes getting to know them as well as she knew her 'girls'. I was in no doubt that my child would be given the very best care and love for the future, I had so much faith in Lil's wisdom and foresight. Later I met a man who invited me out and we began dating and of course I introduced him to Lil. She gave her O.K. and we have been married 44 years now! We both remained friends with Lil and now with her family. I know now, as I predicted then, that my daughter has had a happy, wonderful life.

However, few who now met Mrs. Tate in her professional role would have dreamed of the situations she had been facing for years in her own life. George had become an alcoholic. How did she manage this problem and her long hours of work and still give her boys a good life? Her solution was, as always, a practical one. She aimed to keep them so busy with swimming club, football and Boys' Brigade that they had no time to get into trouble. She involved herself in all these activities, washing the team's rugby jerseys, chaperoning teams or acting as a marshal at sports events. George, who had a strong competitive streak, coached junior rugby for a while. Together they helped to run the church summer camps so that the whole family got their holidays free. The boys had good memories of holidays at Mahurangi, north of Auckland, and trips on the tram to Onehunga to fish off the wharf. Lil provided for them a surprisingly rich childhood and, in spite of everything, they even kept some good memories of George.

At this time the school leaving age was 14 and many children from Ponsonby schools were sent out to work after one year at a technical school. One of the St. James Trustees recommended that she apply for a grant from the Costley Bequest, set up to provide education for children in poor families. For years, this provided her sons with school uniforms, textbooks, glasses and a small allowance. With this help, she supported them at Auckland Grammar - often the only boys from Ponsonby in the top forms - and through their university years. In their bedroom, across the passage from the clothing depot, they worked on their physics and calculus papers. They gained their love of literature from the second-hand 
books they found in old boxes and their love of music from records played on a curious homemade radiogram. Lil was rewarded by seeing them both reach the top of their respective professions.

In the early fifties, George left home and disappeared for good. Lil was in her mid-forties and for the first time in her life she had a secure job and no family secrets to hide. It was at this point and for the next 10 years that 11 Picton Street became the busy cheerful home and Lil the respected social worker that people remember. As a friend, Kay Dixon, wrote, 'The Picton Street house was an open home, people coming and going, family calling in - a cheerful house and always a friendly welcome.' Homeless people were taken in for the night, women fleeing abusive marriages stayed a while to sort themselves out, visiting church workers or friends were in and out, homesick young people new to city life turned up - all would be included in the life of the family. Lil could make an economical Sunday tea of meat loaf and salad, scones and homemade jam seem like a feast to a group of hungry Student Christian Movement students. The hated boarding house had taught her how to manage. The tiny kitchen had no hot water tap so a kettle was always boiling on the gasstove ready for the washing up.

Lil developed strong views on the nature of social work. In the early 1960s when she was near retirement, young social workers, with qualifications in psychology and counselling but limited life experience, began entering the field. She was often scornful of their 'airy fairy' notions and after a seminar recommending 'non-directive counselling' she burst out, thinking of the confused old people she knew, 'Of course I give them direction. If they could sort out their own problems they wouldn't come to see me!' She had no sympathy for laziness and dirt. She would say, 'They were in a real mess so I put the kids in the bath and got a meal on the table. After that we started to get things sorted out.' She had firm views about budgeting and disliked hire purchase. 'If you can't afford it, take it back,' was always her uncompromising advice. In the interview for the Waikato Times Lil stated firmly:

The family work was concerned mainly with problems that arose through the inadequacies of the couple to face their responsibilities. Many of them were young couples who had rushed into marriage without an understanding of the responsibilities it brings.

However she understood the complex and intimate problems faced by women who, like herself, struggled to hold a family together. She dealt with them with great sensitivity and many who came to her as clients became lasting friends. On her retirement she concluded, 'My qualifications are those of years of experience and the tuition I received through working with Sister Esther.'

Two friends have reflected on Lil's particular qualities. In 2003 Kay Dixon wrote:

She was a superb social worker. She stressed the value of social workers' drawing on their own experiences. She was confident that this helped them to handle each case as a separate situation involving different personalities. She herself had learned from her mistakes and she was astute enough to pass this on. A very observant and wise woman.

Jean Alexander was a Deaconess at St. James Church from 1941-48, one of the many able single women attracted to a career in the church at that time. She became a J.P., held responsible positions in Auckland and Christchurch and was on the staff of the Presbyterian journal, The 
Outlook. There are hints that like many idealists, she had found the inner city a tough world. In 1960 she wrote to Lil a warm and perceptive letter, which the family have kept.

Another thing that has gladdened my heart is that you grasped so firmly the opportunity to use your great gifts and have built a work that would stand anywhere. I have seen you do what I once dreamed of doing and I know something of the cost and perhaps some of the satisfactions too. Perhaps the very things you lost gave you what you need to understand and help others.

What then were Lil's essential qualities? Though a church worker she was not a pious woman and I never heard her speak to anyone of sin, salvation or the power of prayer. It seems that the beliefs that guided her work were the beliefs that had guided her life. It was no use dwelling on hard luck or your own mistakes. If there was a problem you looked for a solution. You could go under or you could go forward. She was firm in her judgments and always seemed sure what to do. If she had doubts they were kept as private as the troubles of her personal life. And so people looked to her for support and she gave them strength. She was confident and gave them confidence.

Perhaps living as a child at the end of a bush track in the middle of nowhere teaches you something. Once she was with her mother, when Agnes brought two frightened horses and a dog to safety through a bush-fire. She saw her set off alone on a long ride from Waitewhenua to Te Kuiti with an injured child in the saddle. They were some of the last of the pioneers and she brought their determination and self-reliance to the inner city where repeated knocks caused so many people to give up the struggle.

When I think of her, the word that comes to mind is courage. It is derived from the Latin word for heart, which was regarded not only as the seat of the emotions but of the vital spirit. It is linked in my dictionary with words such as 'vigour' and 'eagerness to act'. It is defined as 'that quality of mind which shows itself in facing danger without fear.'

It is because of her continuing influence on me that I took my daughter to see the old house in Picton Street. It is because of her quality of mind that I am telling her story.

\section{Afterword}

Those were the Auckland years. After George left, Lil developed a strong friendship with Dave Martin, a fellow social worker and former minister who understood her problems and supported her. Since George was a missing person, she could not obtain a divorce for seven years according to the law at that time. Finally in 1962 she became Mrs Martin with a small home in Kihikihi, a large vegetable garden and a path lined with prize gladioli. They quickly became respected members of the small Waikato community. She continued social work in an area covering Hamilton, Waihi, Mangakino, Huntly and Taumarunui, responsible for the placement of children in foster homes and for adoption. In addition she contributed to services in 'Trevelyn' the Presbyterian home for the aged, had a spell as part-time town clerk of Kihikihi and in her late sixties bought a dress shop in Te Awamutu. Dave had died suddenly in 1968. The shop provided her with a new interest and a new group of friends and the venture, approached with her usual vigour and common sense, was a success. She could turn her hand to anything. On December 27th 1976 when her sons and their families 
arrived for the holiday week, they were shocked to find that, in the midst of a happy life, she had died suddenly from heart failure.

Acknowledgements. I should like to particularly acknowledge the invaluable help given me in collecting this material by Wanda Tate, the widow of Lil's son, Ormond, and by Kay Dixon, one of her close friends. I lived in Ponsonby from 1941-1950 and have drawn on my own observations in describing the inner city. I was married to Lil's son, Graham, and enjoyed many conversations with Lil in later life, some of which are quoted as I recall them. This biographical sketch was originally written as an assignment in a Massey University English Department paper which introduced me to contemporary methods in life writing.

\section{References}

Alexander, J. (1960). Letter to Lil Martin, July 1960.

Auckland Presbyterian Orphanages and Social Services Association (Inc). (1959). 45th Annual Report.

Dixon, K. (2003). Personal communication. September 2003.

The Community of St. James. (n.d.). Information brochure, c1959.

McLauchlan, M. (1999). The resurrection of Sister Esther. Northern Notes - Quarterly Journal of Presbyterian Support, Feb.

Waikato Times (1962). Presbyterian Church appoints social worker for the Waikato. 